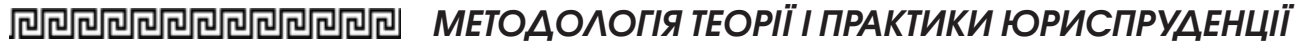

УДК 329.232

DOI https: / / doi.org/10.32837/yuv.v0i6.2028

\author{
М. Пижова, \\ кандидат юридичних наук, \\ доцент кафедри загальноправових дисциплін \\ Інституту управління і права \\ Національного юридичного університету імені Ярослава Мудрого
}

\section{МІНІМАЛЬНА ЗАРОБІТНА ПЛАТА, СПРАВЕДЛИВА ОПЛАТА ПРАЦІ ТА ГІДНИЙ РІВЕНЬ ЖИТТЯ ЛЮДИНИ В КОНТЕКСТІ МІЖНАРОДНОГО ДОСВІДУ}

\begin{abstract}
Аналізуючи інститут оплати праці і досліджуючи питання гарантій реалізації прав працівників на справедливу оплату праці, розуміємо, що фундаментом $€$ питання мінімальної заробітної плати, справедливої оплати праці і акумулюється це в категорії гідний рівень життя людини. Тому i дослідження цих понять взаємопов'язане. Вивчаючи досвід зарубіжних країн із порушених питань, маємо зазначити, що перші закони про мінімальну заробітну плату ставили собі за мету служити гарантом захисту низькооплачуваних, найменш кваліфікованих працівників (зокрема жінок), подолання бідності. Крім того, ситуацію посилювало закінчення Першої світової війни, коли під загрозу була поставлена економічна безпека держав, існувала спільна загроза соціальної нестабільності. У той же час введення таких законів постійно наражалося на опір представників роботодавців. У низці країн тлумачення законодавства про мінімальну заробітну плату як порушення свободи договору шляхом нерозумного втручання держави, під тиском влади роботодавців призвело до анулювання відповідних законів. Прикладом країни, де помічався такий опір, є США. Такі закони були легалізовані через кілька років.
\end{abstract}

Після Другої світової війни в багатьох країнах Європи з'явилися нові закони про мінімальну заробітну плату, сфера дії яких істотно розширилася. Так, закони про мінімальну заробітну плату широкого дії були прийняті і в інших країнах: Іспанії (1963 р.), Нідерландах (1969 р.), Португалії (1974 р.), Бельгії (1975 р.).

Однозначного визначення мінімальної заробітної плати не існувало. Але всюди вона визначалася як «життєва заробітна плата» (living wages), «вартість пристойного існування для робітників», «Плата за потребами». У 1917 р. у Федеральній Конституції Мексики було записано, що мінімальна заробітна плата працівника - глави сім’і має бути достатньою і відповідати умовам проживання в кожному регіоні країни для забезпечення нормальних умов підтримки життєвого рівня, освіти та дозвілля.

Тобто ми бачимо, що навіть у ті часи можна простежити зв'язок категорії «мінімальна заробітна плата», «справедлива оплата праці» і «гідний життєвий рівень людини» (хоча і зауважуємо, що у більшості країн тоді йшла мова про достатній життєвий рівень чи нормальні умови життя).

Спробуємо проаналізувати міжнародні нормативно-правові акти, які містили положення 3 досліджуваних питань. I відразу зазначимо, що найбільше значення в системі 
міжнародно-правового регулювання оплати праці мають правові гарантії, передбачені в нормативно-правових актах Міжнародної організації праці (далі - МОП). Зокрема, особливе місце належить конвенціям і рекомендаціям цієї організації, які присвячені в основному процедурам і принципам установлення державного мінімуму заробітної плати, забезпечення ї̈ охорони 3 метою захисту матеріальних інтересів працівників. Як зазначає С.В. Вишновецька, конвенції МОП, будучи джерелом трудового права України, відіграють особливу роль у практиці правового регламентування праці й мають особливу правову силу, зумовлену тим, що застосування норм про працю, що в них містяться, може бути проконтрольовано не лише судом, а Й безпосередньо МОП. Визнання конвенцій джерелом трудового права України викликає потребу доведення іх до відома широкого кола трудящих мас, оскільки від цього залежить практична ефективність цих документів [1, с. 319]

Так, досвід зарубіжних країн був проаналізований експертами Міжнародної організації праці (далі МОП), була прийнята Конвенція від 16 червня 1928 р. № 26 «Про створення процедури встановлення мінімальної заробітної плати» [2]. Відповідно до Конвенції, встановлений мінімум заробітної плати є обов'язковим для відповідних роботодавців і працівників і не підлягає зниженню ні за індивідуальною угодою, ні якщо тільки немає загального дозволу або дозволу, що стосується окремого випадку, з боку компетентного органу влади - за колективним договором (ст. 3). Працівник, на якого поширюються мінімальні ставки і який отримав заробітну плату за нижчими ставками, має право отримати в судовому порядку або за допомогою іншої законної процедури суму, яка була йому недоплачена, за умови дотримання такого терміну давності, який може бути встановлений національним законодавством (ст. 4). Аналогічне правило міститься в $\mathrm{KoH}_{-}$ венції МОП від 22 червня 1962 р. № 117 «Про основні цілі та норми соціальної політики» (ратифікована Україною 16 вересня 2015 р.).

Трохи пізніше ст. 2 Конвенції МОП від 22 червня 1970 р. № 131 «Про встановлення мінімальної заробітної плати $з$ особливим урахуванням країн, що розвиваються» (ратифікована Україною 19 жовтня 2005 р.) [3] наголосила на юридичному значенні мінімальної заробітної плати: вона не підлягає зниженню, отже, роботодавець не має права платити працівнику заробітну плату нижче такої межі.

Відповідно до міжнародних стандартів рівень мінімальної зарплати розглядається як нижня межа, яка має гарантувати задоволення основних життєвих потреб не тільки трудящого, але і його сім’ї, при цьому, як правило, «набір» таких потреб не визначається, а вказуються можливі критерії ї встановлення. Так, Хартія Європейського співтовариства від 9 грудня 1989 р. «Про основні соціальні права працівників» [4] (не ратифікована Україною) вказує на те, що працівникам має бути забезпечена справедлива заробітна плата, тобто заробітна плата, достатня для того, щоб забезпечувати пристойний (задовільний) життєвий рівень, крім того, встановлюється, що в разі виробництва утримань із заробітної плати мали бути вжиті заходи, що дозволяють продовжувати отримання необхідних коштів для працівника і членів його сім’ї. Ст. 3 Конвенції МОП від 22 червня 1970 р. № 131 «Про встановлення мінімальної заробітної плати з особливим урахуванням країн, що розвиваються» [3], визначаючи рівень мінімальної заробітної плати, також пропонує враховувати потреби не тільки трудящих, але й їніх сімей, беручи до уваги загальний рівень заробітної плати в країні, вартість життя, соціальної допомоги, 


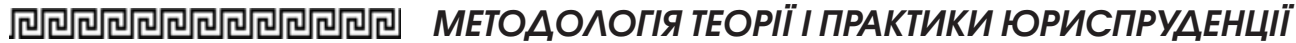

порівняльний рівень життя інших соціальних груп, економічні міркування, рівень виробництва і бажаність досягнення і підтримання високої зайнятості. Відповідно до Європейської соціальної хартії (переглянутої) від 3 травня 1996 р. (ратифікована Україною 14 вересня 2006 р.) з метою забезпечення ефективного здійснення права на справедливу винагороду сторони зобов'язуються:

1) визнати право працівників на таку винагороду, яка забезпечує їм і їхнім сім’ям достатній життєвий рівень;

2) визнати право працівників на підвищену ставку винагороди за роботу в надурочний час з урахуванням винятків, передбачених для окремих випадків;

3) визнати право працюючих чоловіків і жінок на рівну винагороду за працю рівної цінності;

4) визнати право всіх працівників на розумний строк попередження про звільнення з роботи;

5) дозволити відрахування із заробітної плати тільки на умовах і в розмірах, передбачених національними законами або правилами чи встановлених колективними договорами або арбітражними рішеннями [5]. На жаль, ми маємо констатувати, що принцип забезпечення права кожного працівника на своєчасну та в повному розмірі виплату справедливої заробітної плати, що забезпечує гідне людини існування, іï самої та їі сім’і, i не нижче мінімального розміру оплати праці є ратифікованим Україню разом з Європейською соціальною хартією (переглянутою), проте опосередковано відбитим у національному законодавстві і це нині $є$ великою проблемою.

Таким чином, враховуючи аналіз міжнародних нормативно-правових актів, можемо зробити висновок, що мінімальна заробітна плата має встановлюватися 3 урахуванням інтересів працівників, а також членів їхніх сімей. I водночас з урахуванням інте- ресів економічного розвитку. Саме від соціально-економічного становища країни, зрештою, залежить визначення критеріїв встановлення мінімального рівня основних життєвих потреб працівників.

Необхідно зазначити, що розглянуті міжнародні правові акти безпосередньо не називають той «набір» життєво важливих потреб, необхідних для підтримки гідного рівня життя. На відміну від актів МОП, перелік останніх містить Загальна декларація прав людини 1948 р., прийнята Генеральною Асамблеєю ООН. Так, у ній вказується, що кожна людина має право на такий життєвий рівень, включаючи їжу, одяг, житло, медичний догляд та необхідне соціальне обслуговування, який $€$ необхідним для підтримання здоров'я і добробуту ii самої та їі сім’і [6].

Міжнародний пакт про економічні, культурні та соціальні права 1966 р. [7] закріплює право кожного на достатній життєвий рівень для нього і його сім’ї, що включає достатне харчування, одяг і житло, i на неухильне поліпшення умов життя. Тим самим мінімальний розмір оплати праці покликаний виконувати функцію забезпечення гідного рівня життя.

Зазначимо, що Європейський комітет із соціальних прав розробив концепцію порогового рівня заробітної плати, що забезпечує гідний рівень життя, при цьому будь-яка заробітна плата, яка надмірно занижена (порівняно із середнім рівнем у країні) не може забезпечити гідний рівень життя [8]. У сучасній зарубіжній практиці склалися два підходи до цієї проблеми. Перший грунтується на визначенні мінімальних потреб, які необхідно задовольнити для збереження життя. Відповідно до другого підходу, задоволенню на гарантованому мінімальному рівні підлягають не тільки основні фізичні потреби в продуктах і житло, а й соціальні, породжувані соціально-культурним 
розвитком суспільства. У другому випадку рівень мінімальної зарплати співвідноситься з рівнем сформованої заробітної плати. Так, в Японії вона становить близько 44\%, в США близько $50 \%$, у Франції - близько $60 \%$, а в Нідерландах доходить до $75 \%$ середньої зарплати, в Ізраїлі місячний розмір - 47,5\% від середньої заробітної плати. В Україні співвідношення мінімальної і середньої заробітної плати ледь дотягує до 10\% (МОП рекомендує 50\%, Євросоюз $60 \%$ ) [9]. Таким чином, нині рівень мінімальної заробітної плати в зарубіжних країнах вище прожиткового мінімуму (межі бідності), а сама межа бідності - критерій соціальної допомоги, а не регулятор відносин 3 оплати праці. При цьому в зарубіжних країнах мінімальна заробітна плата забезпечує не тільки прожитковий мінімум, а й мінімальні соціальні потреби в освіті, культурному розвитку і т.д., покликані підтримати гідний рівень життя працівника та його сім’і. Своєю чергою в Україні сучасні економічні умови свідчать про те, що встановлення мінімального розміру оплати праці не тільки не гарантує гідне життя, але й не забезпечує прожитковий мінімум значної частини населення.

Важливо також зазначити, що облік розміру мінімальної заробітної плати повинен мати місце в разі захисту вимог працівників за умови неплатоспроможності роботодавця. Саме на це вказує Рекомендація МОП від 23 червня 1992 р. № 180 «Про захист вимог працівників у разі неплатоспроможності роботодавця» [11], в якій говориться, що розмір привілейованого вимоги не має бути нижчим за соціальний і прийнятний рівні.

Варто звернути увагу на два вкрай важливі міжнародні акти 3 питань мінімальної заробітної плати - Конвенція МОП від 22 червня 1970 р. № 131 «Про встановлення мінімальної заробітної плати з особливим урахуванням країн, що розвиваються» [3] і Рекомендація МОП від 22 червня 1970 р. № 135 «Про встановлення мінімальної заробітної плати 3 особливим урахуванням країн, що розвиваються» (вона доповнює Конвенцію № 131) передбачили систему встановлення мінімальної заробітної плати. Остання, згідно з Рекомендацією № 135, включає: 1) єдину загальноприйнятну мінімальну заробітну плату, яка не виключає дію одночасно різних ставок мінімальної заробітної плати в різних регіонах із метою врахування відмінностей у вартості життя; 2) мінімальні заробітні плати для певних груп населення. Отже, допускається диференціація мінімальних розмірів оплати праці.

Водночас маємо також зазначити, що зазначені Конвенція № 131 та Рекомендація № 135 передбачають більш детальну процедуру формування розмірів мінімальної заробітної плати, а також вносять новий, важливий критерій для визначення мінімальної заробітної плати вартість життя в країні. Звертаємо увагу, що ст. 2 Закону України «Про прожитковий мінімум» визначено, що саме прожитковий мінімум застосовується для загальної оцінки рівня життя в Україні.

Маємо зауважити, що в нашій державі була спроба зміни підходів до встановлення розмірів посадових окладів. Так, 13 січня 2020 р. був зареєстрований проєкт закону «Про внесення змін до деяких законодавчих актів України щодо створення передумов для підвищення прожиткового мінімуму» № 2720. Цим законопроєктом передбачалося внесення змін до законодавчих актів України щодо зміни підходів до встановлення розмірів посадових окладів, а саме залежно не від прожиткового мінімуму, а від мінімального розміру посадового окладу для відповідних категорій працівників, який передбачається затверджувати законом про Державний бюджет України на відповідний рік. Важливе, що передбачалося цим 


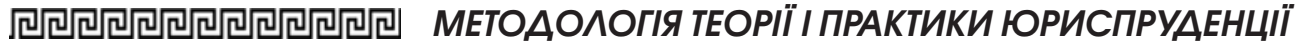

законопроєктом, - це виключення зі ст. 95 Кодексу законів про працю України та ст. 9 Закону України «Про оплату праці» норми щодо встановлення розміру мінімальної заробітної плати не нижче від розміру прожиткового мінімуму для працездатних осіб. Зазначалося, що ця пропозиція суперечить положенню ст. 3 Конвенції МОП № 131 (про яку ми вже зазначали), де наводиться низка факторів, які враховуються державами-членами під час встановлення рівня мінімальної заробітної плати, зокрема прожиткового мінімуму. Однак 4 березня вказаний законопроєкт було відкликано. Ми вважаємо, що проблема полягає в несистемному підході до реформування інституту оплати праці.

Також маємо зазначити, що відповідно до підпункту «а» статті X частини II Декларації соціального прогресу та розвитку ООН, прийнятої резолюцією 2542 (XXIV) Генеральної Асамблеї від 11 грудня 1969 р. соціальний прогрес і розвиток мали бути спрямовані на постійне підвищення матеріального i духовного рівня життя всіх членів суспільства, шляхом досягнення такої головної мети - встановлення мінімального рівня заробітної плати, досить високого для забезпечення задовільного рівня життя.

Вірно зазначає Я.В. Сімутіна, що дослідження міжнародного законодавства з метою використання позитивного досвіду правового регулювання винагороди за працю у трудових відносинах, а також гармонізація законодавства України 3 міжнародним законодавством, що $є$ необхідною умовою для входження України до міжнародних організацій, зокрема до Європейського Союзу, свідчать, що міжнародні норми, присвячені питанням заробітної плати, активно впливають на національне законодавство, визначають його принципи і напрями [10, с. 149].

Таким чином, ми робимо висновок: вивчення досвіду зарубіжних країн та положень міжнародних нормативно-правових актів дає підстави стверджувати, що особливу увагу під час розбудови інституту оплати праці варто приділяти гарантіям прав працівників на справедливу оплату праці. Оскільки ця категорія нерозривно пов'язана і з мінімальною оплатою праці, і зі справедливою оплатою праці, і з гідним рівнем життєдіяльності людини. А це своєю чергою $€$ базис, який тим чи іншим чином знаходить відбиття в конституціях держав.

у статті висвітлюються питання мінімальної заробітної плати, справедливої оплати праці та гідного рівня життедіяльності людини в контексті міжнародного досвіду. Вказується, що ядром категорії гарантї реалізаціі прав працівників на справедливу оплаmу праці є питання мінімальної заробітної плати та справедливої оплати праціi. Підкреслюеться, щзо перші закони про мінімальну заробітну плату мали за мету служити гарантом захисту низькооплачуваних, найменш кваліфікованих працівників (зокрема, жінок), подолання бідності. Аналізуються Конвенціі Міжнародної організації праці з порушеного питання. При цьому зазначається, що мінімальна заробітна плата мае встановлюватися з урахуванням інтересів працівників, а також иленів їхніх сімей, $i$ водночас з урахуванням інтересів економічного розвитку. Саме від соціально-економічного становища країни залежить визначення критерїв встановлення мінімального рівня основних життевих потреб працівників. Констатується, щзо принщиип забезпечення права кожного працівника на своєчасну та в повному розмірі виплату справедливої заробітної плати, щзо забезпечуе гідне людини існування, ï самої та ї̈ сім'ї $і$ не нижче мінімального розміру оплати праці, $\epsilon$ 
ратифікованим Україною разом з Європейською соціальною хартією (переглянутою), проте опосередковано відбитим у національному законодавстві $i$ ије нині $\epsilon$ великою проблемою.

Вивчення досвіду зарубіжних країн та положень міжнародних нормативно-правових актів дає підстави стверджувати, що особливу увагу під час розбудови інституmy оплати праці варто приділяти гарантіям прав працівників на справедливу оплату праці, оскільки ия категорія нерозривно пов'язана $i$ з мінімальною оплатою праці, $i$ зі справедливою оплатою праці, $i$ з гідним рівнем життєдіяльності людини. А цее своєю чергою є базисом, який тим чи іншим чином знаходить відбиття в конституцуіх держав.

Ключові слова: мінімальна заробітна плата, справедлива оплата праці, гарантії прав працівників, гідний рівень життєдіяльності, гідні умови життя, достатній рівень життя.

Pyzhova M. Minimum wages, fair wages and a dignified level of life in the context of international experience

The article covers the issues of the minimum wage, fair wages and a decent standard of living in the context of international experience. It is pointed out that the core of the category of guaranteeing the realization of workers' rights to fair wages is the issue of minimum wage and fair wages. It is emphasized that the first laws on the minimum wage aimed to guarantee the protection of low-paid, low-skilled workers (including women) and overcoming poverty. The International Labor Organization Conventions on this issue are analyzed. It is noted that the minimum wage should be set taking into account the interests of employees and their families. And, at the same time, taking into account the interests of economic development. It is the socio-economic situation of the country that ultimately determines the criteria for establishing the minimum level of basic living needs of workers. It is stated that the principle of ensuring the right of every employee to timely and full payment of a fair wage that provides a decent living, himself and his family, and not less than the minimum wage is ratified by Ukraine together with the European Social Charter (revised), but indirectly reflected in national legislation and this is currently a major problem.

It is concluded that the study of the experience of foreign countries and the provisions of international regulations gives grounds to argue that special attention during the development of the institution of remuneration should be paid to guarantees the rights of workers to fair remuneration. Because this category is inextricably linked with the minimum wage, and fair wages, and a decent standard of living. And this in turn is the basis, which in one way or another is reflected in the constitutions of states.

Key words: minimum wage, fair wages, guarantees of workers' rights, decent standard of living, decent living conditions, sufficient standard of living.

\section{Література}

1. Вишновецька С.В. Міжнародні аспекти захисту прав людини у сфері пращі. Острозька академія : наукові записки.Серія «Право». Острог: Наи.ун-т «Острозька академія», 2002. С. 318-323.

2. Про створення процедури встановлення мінімальної заробітної плати : Конвенція МОП від 16 червня 1928 р № 26. URL: https: / / zakon.rada.gov.ua/laws / show/993_196\#Text.

3. Про встановлення мінімальної заробітної плати з особливим урахуванням країн, що розвиваються : Конвенція МОП від 22 червня 1970 р № 131. URL: https: / / zakon.rada.gov.ua/laws / show/993_149\#Text.

4. Хартія Європейського співтовариства від 9 грудня 1989 г. «Про основні соціальні права працівників». 


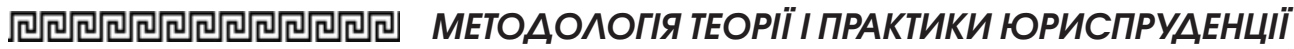

URL: https: / / zakon.rada.gov.ua/laws/ show/994_044\#Text.

5. Європейська соціальна хартія (переглянута) від 3 травня 1996 р. URL: https: / / zakon.rada.gov.ua/laws / show/994_062\#Text.

6. Загальна декларація прав людини. URL: https: / /zakon.rada.gov.ua/laws / show/995_015\#Text.

7. Міжнародний пакт про економічні, культурні та соціальні права. URL: https: / zakon.rada.gov.ua/laws/ show/995_042\#Text.

8. Достойная оплата труда - цель и средство повышения уровня жизни. Человек и труд. 2002. № 8. С. 71-78.
9. Лучкина Л.С. Проблемь социальной защиты населения и прожиточный минимум: опьт стран Центральной и Восточной Европы. Труд за рубежом. 1998. № 2. C. 33-39.

10. Сімутіна Я.В. Методи регулювання заробітної плати на сучасному етапі (правові проблеми) : монографія. Київ : Київський університет права НАН України, 2009. 176 с.

11. Про захист вимог працівників у разі неплатоспроможності роботодавия : Рекомендація МОП від 23 червня 1992 № 180. URL: https://zakon.rada. gov.ua/laws/show/993_168\#Text. 